\title{
Historical Mining Signatures: Geochemical and Mineralogical Evaluation of Sediments in three Coastal - Estuarine Systems
}

\section{Temitope D. Timothy Oyedotun *}

Department of Geography and Planning Sciences, Adekunle Ajasin University, Ondo State, Nigeria

*Corresponding author: Temitope D. Timothy Oyedotun, Department of Geography and Planning Sciences, Adekunle Ajasin University, P. M. B. 001, Akungba-Akoko, Ondo State, Nigeria, Tel: +234-813-86602; E-mail: oyedotuntim@yahoo.com

Received date: August 05, 2016; Accepted date: August 19, 2016; Published date: August 26, 2016

Copyright: (C) 2016 Oyedotun TDT. This is an open-access article distributed under the terms of the Creative Commons Attribution License, which permits unrestricted use, distribution and reproduction in any medium, provided the original author and source are credited.

\begin{abstract}
The X-ray fluorescence (XRF) of the inter-tidal sediments in Hayle, Gannel and Camel estuaries in southwest England's coasts are examined here to evaluate and compare the broad geochemistry of each of the three systems. The total base cation content ( $\mathrm{Na}, \mathrm{Mg}$ and $\mathrm{K}$ ) of the samples in all of the estuaries is $5 \%$ while the $\mathrm{Ca}$ is $\sim 20 \%$. In terms of sub-environment significance, the estuarine and inlet sediments of Hayle exhibit a high content of $\mathrm{Ca}$ than the coastal/beach samples while both the Gannel's estuarine and beach samples exhibit $\sim 25 \%$ of Ca composition. There is high variation in the dimension of $\mathrm{Ca}$ in the different sub-environments sampled in Camel estuary (outerestuary $-25-28 \%$, mid-estuary - $20 \%$, inner $-30 \%$ ). The Al and Fe contents in all of the sites are below $2 \%$ except in Camel where $\mathrm{Al}$ is around $3.5 \%$. There clear difference in the percentage of composition of trace elements among the estuaries is also evident. Sn's concentration in Hayle is higher than that of Camel and Gannel. $\mathrm{Pb}, \mathrm{Ba}, \mathrm{Zr}$ and $\mathrm{Zn}$ is significant in all of the estuaries at various degrees - $\mathrm{Pb}$ and $\mathrm{Zn}$ are abundant in Gannel, while $\mathrm{Sn}, \mathrm{W}, \mathrm{Zr}$ prominent in Camel. The significant effect of the release of the particulate mine waste are observed in the samples' mineralogical composition despite the cessation of the mine activities in the 19th/early 20th Century, suggesting that these elements are still bio-available and bio-active for riverine processes to transport/migrate in the estuary-coast interaction.
\end{abstract}

Keywords: XRF; Inter-tidal sediment; Major element; Minor element; Particulate mine waste; Hayle estuary; Gannel estuary; Camel estuary

\section{Introduction}

Coastal and estuarine environments have had long and varied history of anthropogenic interference and these are being studied intensively because of the persistent presence of metals which pose environmental risks to both humans and ecosystems [1]. Indeed, many estuarine and coastal systems are increasingly affected by the release and deposition of heavy metals from the varied anthropogenic activities [2,3]. Most of the world's urban areas and economically active cities are located in the coastal zone and it is also the region to which anthropogenic wastes are discharged -including the release of trace metals in significant amount on many occasions [4]. It is argued that if humans had not sought to make use of the coastal-estuarine environment/zone, there would have been few environmental problems [5]. Thus the presence of humans in the coastal environment is argued to interfere and modify the coastal systems causing many environmental challenges in many parts of the world [6]. Toxic metals discharged into estuarine-coastal environments always settles and become incorporated into the sediments [7]. The sediments in the coastal/estuarine environments are often regarded as the prime reservoir of heavy metals in the coastal zone [8]. Geochemical investigations based on mineralogical and chemical analysis in coastalestuarine environments are effective scientific tools with many applications $[8,9]$. Principally, such investigations were initially used as exploration tools $[7,8]$ and of recent for environmental studies and purposes [8].
In the present study, the surface sediments from three distinct coastal-estuarine environments in southwest England are sampled for environmental investigations of impact of historical mining signatures on marine sediments. The purpose of this study is to confirm whether there is any strong sedimentary link between heavy metal contamination and historical mining activities in the region. Sediment's geochemical and mineralogical studies are useful in metal pollution investigation as they have long residence time in estuarinecoastal areas [1]. The present study complements the previous works in the region by exploring the sedimentary connectivity of the system through the evaluation of the geochemical composition of the intertidal sediments within the sedimentary environments in all of the three estuaries shortlisted for this study (the Hayle, Gannel and Camel estuaries respectively).

\section{Materials and Methods}

\section{Southwest England case study}

United Kingdom (UK) is very rich in estuaries (over 160 according to Defra [10] with more than a quarter of the northwestern European estuaries occurring in the UK [10]. The Hayle, Gannel and Camel estuaries and their adjacent open-coast beaches (Figure 1), which are three neighbouring systems, provide an excellent opportunity to investigate the extent to which the diverse historical mining activities exhibit any regional coherence. The Hayle Estuary lies within St Ives Bay in the Penwith District of Cornwall in Southwest England (Figure 1). St Ives Bay is approximately $6.5 \mathrm{~km}$ wide, and the Hayle inlet lies just west of the centre of the bay. The bay is considered to be a closed sediment cell, suggesting that over the mesoscale, the sediment budget is balanced by morphodynamic adjustment across the estuary, inlet, 
beaches and nearshore [11]. Site A, in the inner estuary (Lelant water/ Carrack Gladden; Figure 1) is a broad intertidal flat while sites B and D are sandy planar upper foreshore which merge with a broader and flatter beach at the inlet of the Hayle estuary (site C).

The Gannel Estuary is 70\% intertidal estuarine valley [12] situated in Newquay, between Pentire Point East and Pentire Point West, on the coast of Cornwall, South-West England (Figure 1).

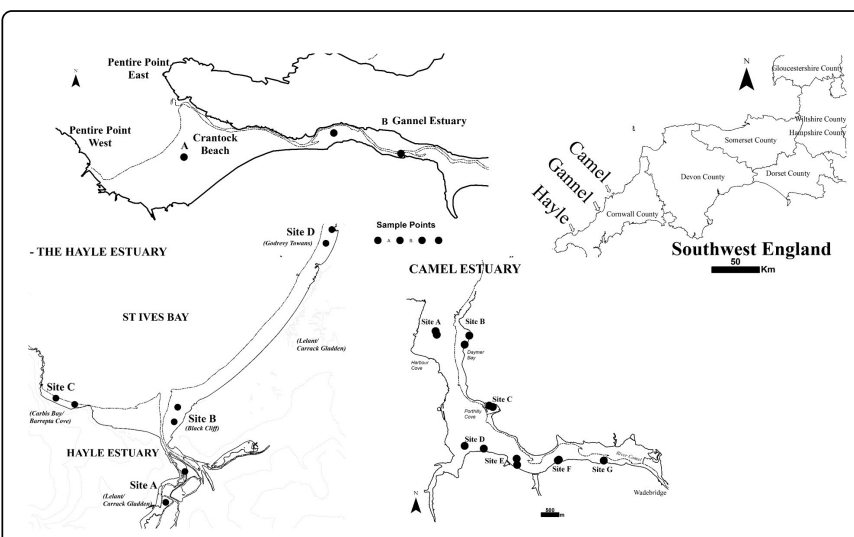

Figure 1: The Hayle, Gannel and Camel Estuaries (Cornwall, Southwest England) showing the sampling sites considered in this study.

This coastline is macrotidal and the estuarine environment is a saltmarsh ria system comprising sandy intertidal sediments which merged through a narrow valley to a sandy beach-dune system (Crantock) seaward [13]. The Devonian slate/sandstone headlands of Pentire Points East and West ensure the system functions as a selfcontained sediment cell [14].

The Camel Estuary, adjacent to Padstow, also in Cornwall, southwest England (Figure 1), is a shallow, predominantly sandy ria estuarine system formed as a product of post-glacial rise in sea level $[15,16]$. The main sedimentary environments in the estuary include sand dunes, saltmarsh, sand flats, mud flats, subtidal channels, and grazing marsh [15-17]. The Camel Estuary is also more sheltered, which enables the system to function as an important sediment sink $[16,18]$.

\section{Field sampling}

Surface sediments samples were collected from the intertidal zone of estuaries and along the beaches. Sample locations were located randomly within individual and key sedimentary sites in each system, and positioned using a hand-held Global Positioning System (GPS), ( $\pm 3 \mathrm{~m}$ rms error). An effort was made to ensure that sufficient samples were collected from within the estuaries and along the beach areas, across the full intertidal zones. Samples acquired at low tide, were sealed, tagged and returned to the laboratory intact.

\section{XRF analysis}

The XRF is used here to examine the sedimentological characterisation of sedimentary environments within, and connectivity between, the estuary and open coast system in Hayle, Gannel and Camel Estuaries respectively. X-ray Fluorescence Spectrometry (XRF) is used to determine the major oxide and trace element composition of sediment samples [19]. The major and trace elements in their oxidised state are determined as percentage of composition. Major geochemical element analysed (XRF) here are: Ca (Calcium), Si (Silicon), Al (Aluminium), $\mathrm{Fe}$ (Iron), $\mathrm{Cl}$ (Chlorine), $\mathrm{Mg}$ (Magnesium), $\mathrm{Na}$ (Sodium), K (Potassium), Ti (Titanium), S (Sulphur), P (Phosphorus), Mn (Manganese), V (Vanadium), and Cr (Chromium). The trace elements analyse are: Ti (Titanium), $\mathrm{Cr}$ (Chromium), Co (Cobalt), $\mathrm{Sr}$ (Strontium), Se (Selenium), Sb (Antimony), U (Uranium), Zn (Zinc), $\mathrm{Br}$ (Bromine), Zr (Zirconium), Ba (Barium), Ce (Cerium), Pb (Lead), (Copper), Ga (Galium), Ce (Cerium), As (Arsenic), Rb (Rubidium), Y (Yttrium), Mo (Molybdenum), Ag (Silver), Sn (Tin), Te (Tellurium), I (Iodine), Cs (Caesium), La (Lanthanum), Hf (Hafnium), Ta (Tantalum), W (Tungsten), TI (Thallium), Bi (Bismuth), and Th (Thorium) respectively. The samples used in the XRF analyses were obtained from $0-5 \mathrm{~cm}$ sediment depth from a range of estuarine and open coastal sample locations (Figure 1). The major elements are determined as a percentage composition [20] while the minor/trace elements analysis are undertaken to obtain data in concentrations of one to several tons and parts per million (microgram-mg or a gram g).

The samples were freeze-dried at $60^{\circ} \mathrm{C}$ in MODULO $4 \mathrm{k}$ Freeze Drier for five days before the dried samples were pulverised into a fine powder using an agate mortar and pestle. Each pulverised ground sample was then weighed prior to analysis and the weight for each of the 21 samples ranged from 4 to 6 grams. These subsamples were analysed using a Spectro XLab Pro 2000 to produce the high X-ray intensity, which permits the quantitative analysis of elements in the $n g$ range.

The generated data were then analysed in Matlab and Paleontological Statistics (PAST) software [21] for comparison of major and minor/trace element composition across the three systems while the geospatial comparison of some major and minor elements composition were explored in ArcGIS. Major elements were measured in percentage (\%) while trace elements were measured in $\mu \mathrm{g} / \mathrm{g}$.

\section{Results}

\section{Elemental composition of intertidal sediments}

The comparative major and minor/trace elemental analysis of the samples in the systems are presented in Figures 2-5. The comparison of total base cation content ( $\mathrm{Si}, \mathrm{Mn}, \mathrm{P}, \mathrm{CI}$ and $\mathrm{Fe}$ ) of the Hayle estuaries is high compared to total content analysed for other estuaries while $\mathrm{Mg}$, $\mathrm{Al}, \mathrm{S}$, and $\mathrm{K}$ of the major elements considered are, however, higher in Camel Estuaries (Figure 2).

The total base cation content $(\mathrm{Na}, \mathrm{Mg}$ and $\mathrm{K})$ is low $(<5 \%$ in total) in all of the sites with the exception of Ca which is much higher $(\sim>=$ 20\%). Patterns in Ca distribution at the systems are broadly similar across the sites. Shell material was clearly present in the sediments sampled, and fragments are noted to contribute to the medium and coarse sand size populations. However, in all of the estuaries, $\mathrm{Na}, \mathrm{Mg}$, $\mathrm{Si}, \mathrm{S}$, and $\mathrm{K}$ have relative lower percentage (0.1-6\%) of composition.

The summary comparisons of major elemental composition between the estuarine sediments and the beach/coastal sediments can be observed from the Figures 2 and 3.

The beach sediments in Hayle (Figure 3 ) have higher content of $\mathrm{Si}$, $\mathrm{Al}$ and $\mathrm{Fe}(\sim 13 \%, \sim 2 \%$ and $\sim 2 \%)$ than estuarine $(\sim 8 \%, \sim 1.5 \%$ and $\sim 1.5 \%)$ sediments respectively, while there is no significant difference in the elemental compositions of these major elements between the coastal and estuarine sediments in Gannel. 


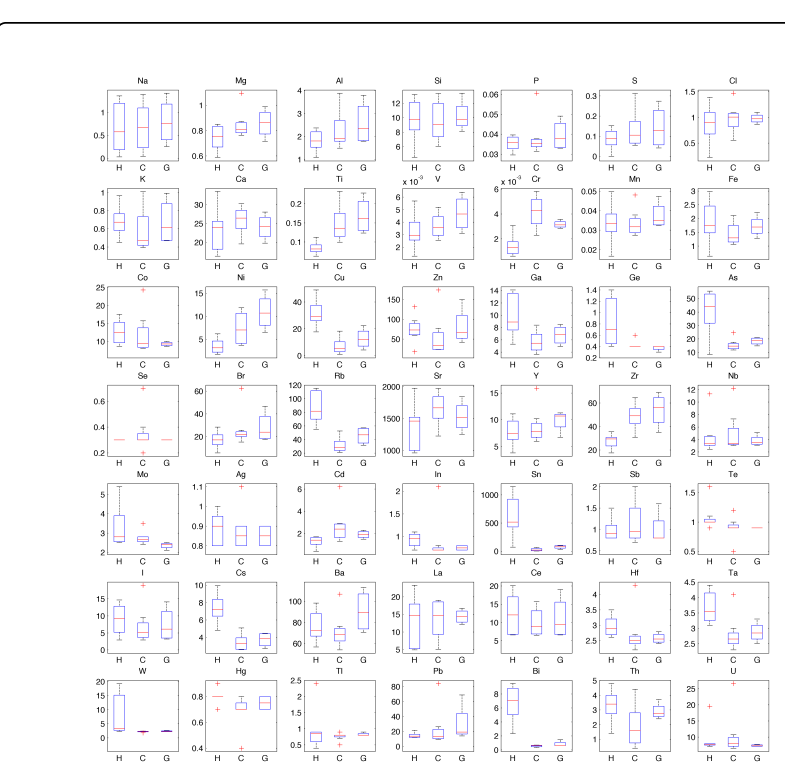

Figure 2: Comparison of major ( $\mathrm{Na}$ to $\mathrm{Fe}$ ) and minor/trace (Co to $\mathrm{U})$ element composition across the three sites ( $\mathrm{H}$ - Hayle; $\mathrm{C}$ Camel; G - Gannel). Elements Na to Fe are measured in \%; elements Co to $\mathrm{U}$ are measured in $\mu \mathrm{g} / \mathrm{g}$.

In another comparison, the beach sediments in Hayle have lower content of $\mathrm{Ca}(\sim 20 \%)$ than its composition in the estuarine ( $34 \%)$ sediments. Similarly, in Gannel, there is no significant difference in the percentage elemental dimensions of $\mathrm{Ca}$ in both estuarine ( 20 - 28\%) and beach ( 25\%) sediments. In Camel estuary, however, the seaward sites $(\mathrm{A}-\mathrm{B})$ have lower content of $\mathrm{Al}, \mathrm{Si}$ and $\mathrm{Fe}(\sim 2 \%, \sim 8 \%$ and $\sim 2 \%)$ compared to the mid-estuarine samples (Sites C \& D, which are $\sim 4 \%$, $\sim 12 \%$ and $\sim 2 \%$ ) and inner-estuarine samples (Site F, which are $\sim 3 \%$, $\sim 13 \%$ and $\sim 2 \%$ ) respectively. Comparatively, in Hayle, the estuarine and inlet samples (Site A and C) exhibit a higher content (23-33\%) of Ca than the open coast/beach sample (Site D) (16-19\%) (Figures 2 and 3 ). In the Gannel, both the estuarine and beach samples exhibit the similar proportions of $\mathrm{Ca}$ (19-28\%). Calcium in the Camel varies spatially: the outer estuary has a high percentage (sites A-C between $25-28 \%)$, the mid- and far inner estuary slightly less ( $20 \%$ at sites D \& $\mathrm{F})$. Site $\mathrm{E}$ in the inner estuary has the highest concentration of $\mathrm{Ca}$ at around $30 \%$. This is the opposite trends observed for $\mathrm{Al}, \mathrm{Fe}$ and other related major elements. The $\mathrm{Al}$ and $\mathrm{Fe}$ contents across all sites are around 1-3\% except in Camel Sites C, D \& F where the $\mathrm{Al}$ is around $3.5-4 \%$.

The geochemical profile of the trace elements sampled for analysis for the estuaries show $\mathrm{Ti}, \mathrm{Cr}, \mathrm{Co}, \mathrm{Sr}, \mathrm{Se}, \mathrm{Sb}$, and $\mathrm{U}$ are abundantly registered in Camel compared to Hayle and Gannel while $\mathrm{V}, \mathrm{Zn}, \mathrm{Br}, \mathrm{Zr}$, $\mathrm{Ba}, \mathrm{Ce}, \mathrm{Hg}$, and $\mathrm{Pb}$ are higher in Gannel Estuary and $\mathrm{Cu}, \mathrm{Ga}, \mathrm{Ce}, \mathrm{As}$, Rb, Y, Mo, Ag, Sn, Te, I, Cs, La, Hf, Ta, W, TI, Bi and Th in Hayle respectively (Figures 2 and 4). Trace elements such as $\mathrm{Zn}, \mathrm{Rb}, \mathrm{Sn}, \mathrm{Sr}$, $\mathrm{Zr}, \mathrm{Ba}, \mathrm{Pb}, \mathrm{Ce}, \mathrm{La}$, have high concentrations in all of the samples when compared with other elemental dimensions. There is over $55 \%$ concentration of $\mathrm{Zn}$ in all of the samples in Hayle and Gannel $(>70$ $\mu \mathrm{g} / \mathrm{g})$, which are higher than the concentrations in the outer-estuarine samples of Camel estuary (Sites A - B, $(\sim 25-28 \mu \mathrm{g} / \mathrm{g})$, Figures 2 and 4). It is only the mid-inner estuarine samples in Camel (Sites C - F) which exhibit a significant composition of these elements $(\sim 70->170$ $\mu \mathrm{g} / \mathrm{g})$. The coastal/beach sediments of Hayle Estuary have higher composition of $\mathrm{Rb}(>100 \mu \mathrm{g} / \mathrm{g})$, than estuarine samples $(\sim 75 \mu \mathrm{g} / \mathrm{g})$, while they are of low content in Gannel $(<60 \mu \mathrm{g} / \mathrm{g})$ and Camel $(<50$ $\mu \mathrm{g} / \mathrm{g}$ ) estuaries respectively (except at site $\mathrm{F}$, the inner estuary in Camel).

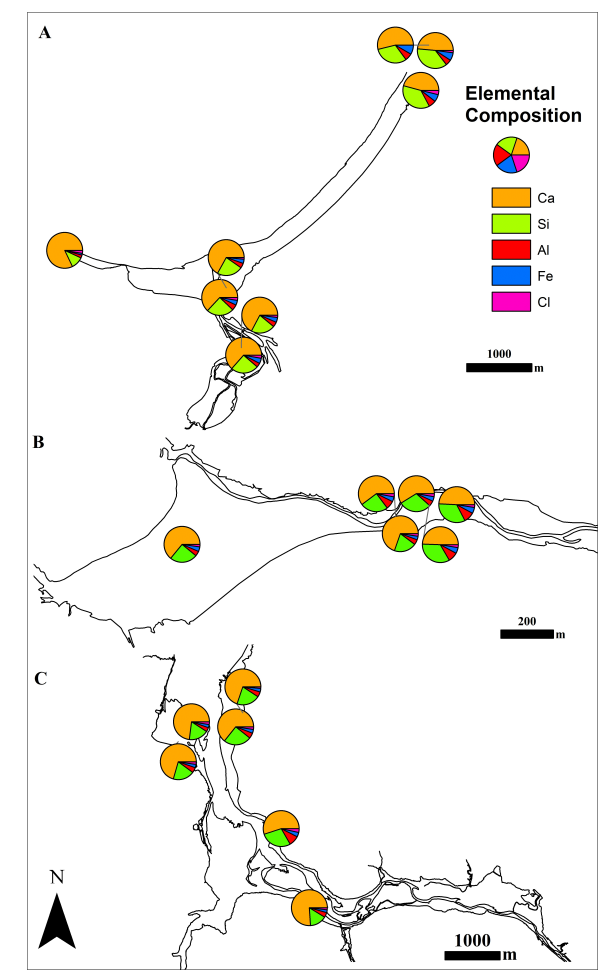

Figure 3: Comparative sample of some major elemental composition in the estuaries (A - Hayle; B - Gannel; C - Camel Estuaries respectively).

The composition at the coastal sediments of site $\mathrm{D}$ in Hayle is lower than that of other concentration in the samples. The $\mathrm{Zr}$ composition in Gannel and Camel estuaries are higher $(>35 \mu \mathrm{g} / \mathrm{g})$, than sediments' composition of this element in the Hayle Estuary $(<\sim 35 \mu \mathrm{g} / \mathrm{g})$, while it is a different scenario for the $\mathrm{Sn}$ concentration as there are higher concentration of this element in Hayle $(>400 \mu \mathrm{g} / \mathrm{g})$, than in the Gannel $(<\sim 107 \mu \mathrm{g} / \mathrm{g})$ and Camel $(<30 \mu \mathrm{g} / \mathrm{g})$ estuaries. $\mathrm{Ba}$ and $\mathrm{Pb}$ are also of notable composition ( $>50$ and $>10 \mu \mathrm{g} / \mathrm{g}$ respectively) in all of the sites with the significant dimension of concentration recorded in Camel's inner estuarine samples at site $\mathrm{F}$ (>106 and $84 \mu \mathrm{g} / \mathrm{g}$ respectively) (Figure 2).

$\mathrm{Sr}$ is strongly associated with $\mathrm{Ca}$ and it is therefore strongly present where $\mathrm{Ca}$ is apparent in all of the three systems (Figure 4).

Sr content in sediments are highly controlled by combination of parent rock materials and climate, and therefore its concentration is higher with a range of $50-1000 \mathrm{mg} \mathrm{kg}^{-1}$ [22]. Here, the composition of $\mathrm{Sr}$ is higher in all of the sample sites $(>1000 \mu \mathrm{g} / \mathrm{g})$ except at Hayle beach Site D where it is less than $(<) 1000 \mu \mathrm{g} / \mathrm{g}$. Although $\mathrm{Sr}$ is easily mobilised and derived during weathering processes, notably in oxidising acidic environments, it can also be incorporated in clay materials and fixation of organic materials [22]. The anthropogenic 
sources from industrial waste, especially from $\mathrm{Zn}$ refineries, incineration ash and disposal of coal ash are other possible derivation of $\mathrm{Sr}$ in sediments [23]. The samples in all of the sites exhibit a reasonable high percentage of $\mathrm{Si}$ dimension with $\mathrm{Si}$ being prominent at samples across the seaward/coastal zones, reflecting the importance of the quartz component. The proportions associated with the other major elements, for these samples, are minimal (Figures 2 and 4).

The result of the Principal Component Analysis (PCA), using the correlation-type in Paleontological Statistics (PAST) software is presented in Figure 5. The first three main eigenvalues (12.09, 8.9, and 3.79 ) of the nineteen values in the analysis correspond to $35.6 \%, 26.2 \%$ and $11.2 \%$ of the total variance respectively.

Thus the first two principal components (PC), presented as Biplot in Figure 5, provides the basic information about the differences in the elemental composition. The $\mathrm{x}$-axis presents the $\mathrm{PC} 1$ while the $\mathrm{y}$-axis indicates the PC2 of the elemental composition. Quite a lot of the minor elements are at/just above detection level and therefore are ignored in the detailed analysis. Here, the difference between the Hayle and the other two estuaries are obvious. Specifically, the Hayle is much higher in metal pollutants than the other estuaries, and much lower marine carbonates (Ca, Sr) (Figures 2-4).

The inclusion of the grain size statistics did not really change the pattern of results (in the PCA analyses), but it shows that coarser grain sizes in the Hayle are rather more strongly associated with the metals $\mathrm{Cu}$ and $\mathrm{Sn}$, but not associated with the metals $\mathrm{Pb}$ and $\mathrm{Fe}$.

\section{Discussion}

\section{Geochemical and mineralogical composition of sediments}

The mineralogical and geochemical investigation of sampled sediments, in addition to other similar previous studies in the region (e.g., [24-29], etc.) showed that the estuaries have retained sediments which are significantly enriched in $\mathrm{Si}, \mathrm{Al}, \mathrm{Na}, \mathrm{Fe}, \mathrm{Cl}, \mathrm{K}, \mathrm{Sn}, \mathrm{Sr}, \mathrm{Zn}, \mathrm{Zr}$, $\mathrm{Ba}, \mathrm{Rb}, \mathrm{Y}$, and $\mathrm{W}$. These geochemical and mineralogical compositions in the sedimentary systems indicate the signature of historical impact of industrial activity on the sedimentary environment [29]. The intertidal sediments of the three estuaries clearly show the release of mine waste tailings into the estuarine catchments leading to and resulting in enhanced siltation [28]. $\mathrm{Sn}, \mathrm{Cu}$, As and $\mathrm{Zn}$ are significant in the Hayle estuary, $\mathrm{Pb}$ and $\mathrm{Zn}$ are important in the Gannel estuary and $\mathrm{Sn}, \mathrm{W}$ and $\mathrm{Zr}$ are enriched in the Camel estuary respectively. Specifically, the Hayle is much higher in metal pollutants than the other estuaries, and the proportion of marine carbonates is much reduced $(\mathrm{Ca}, \mathrm{Sr})$.

The history of mining activities in the region and their impact are well-documented. Despite the cessation of mining activities in the region in over 100 years ago [29], the geochemical and mineralogical of the intertidal sediments clearly retain the legacy of these human activities.

The presence of mining contamination at the beaches and the open coast indicates that there is a sedimentary connection between the estuary and the beach, and also attest to the historical impact of the anthropogenic activities on the estuarine sediment systems. The evidence from the geochemical analyses of the sediments is an indication of the reworking of waste derived originally from the past mining activities through the riverine inputs $[28,30]$.

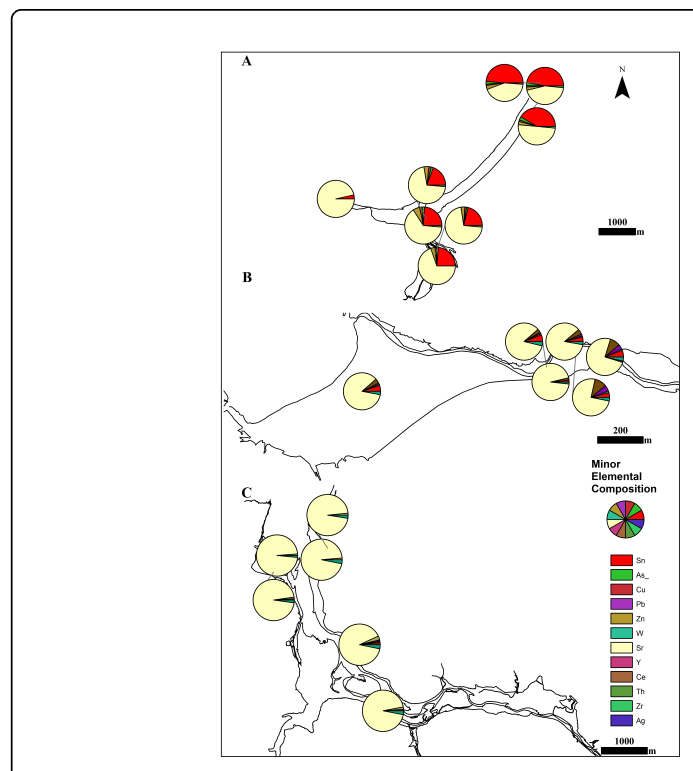

Figure 4: Comparative sampling of some minor elemental composition in the systems (A - St Ives-Hayle; B - CrantockGannel and C - Padstow-Camel systems respectively).

Findings in the data indicate that mine waste tailings have been deposited within the estuaries but hydrodynamically transported to the estuary mouth and open coast. The geochemistry and mineralogy of sediments from the sites here can be compared with other estuaries in Cornwall where hard-rock mining activities have resulted in siltation, for example in the Fowey Estuary [28] and Fal Estuary [31].

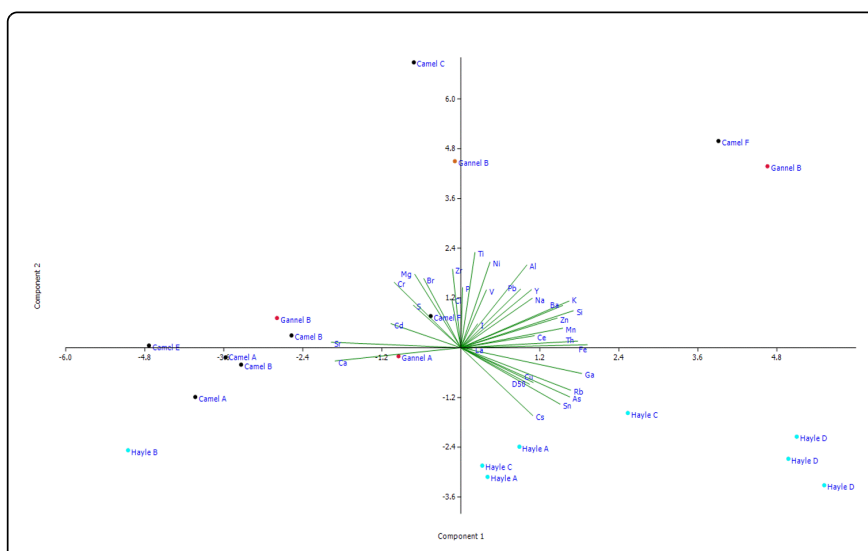

Figure 5: Principal Component Analysis (PCA, using correlationtype in PAST) of the elemental (XRF) composition (\%) of intertidal sediments and the grain-size (represented as D50). (Note: colour representation: Hayle - light green dot, Gannel - Red dot , and Camel - Dark brown dot).

The geochemical signature of the elements composition in the estuaries, as evidenced from the XRF analysis of some of the samples and other previous works on the study sites, confirmed that sediments 
supplied to the estuaries and coastal zones of the region were derived either from (i) the offshore during the early Holocene as a result of the sea-level rise which flooded the region [28]; (ii) onshore as a result of terrestrial transportation of sediment through the hydrodynamic action of the river system [25,32]; or, (iii) most recently, through the human activity as a result of the release of particulate waste from major historical mining which contributed immensely to the siltation and supply of the sediments in the region [25]. However, considering the geochemical elements of both beach and estuarine environments' sediment samples, there is a possibility that the beach and coastal sands in the vicinity of the bays (especially those at the entrance channels) are caught up by the ebb and flood of the tide, then carried in and out of the estuaries.

\section{Evidence for sediment sources}

The current coastal and estuarine sediment build-up is as a function of either onshore or offshore supply of natural sediments coupled with supplies arising from human activities [26]. Cornish estuaries have received considerable attention regarding sediment geochemistry principally as a result of past mining activities in the region. The distribution of $S n$ and other heavy materials in the superficial portion of the sediments in Hayle Beach area can be attributed to the transportation of mine waste by the River [33]. Although the River Hayle is very active in the estuary and drains a significant part of the mining area, Pirrie and Camm [25] observed that River Hayle alone could not have supplied much of such sediment to Hayle's beach as the estuary acts as an "efficient sediment trap". The major mining operation areas, numerous smelting/mineral processing plants and tin processing plants contributed to the discharge of large volumes of fine sediments enriched in $\mathrm{Sn}, \mathrm{Cu}, \mathrm{As}$ and $\mathrm{Zn}$ [28]. Hayle was important sites for $\mathrm{Cu}, \mathrm{Sn}$ and large scale tin smelting and iron foundry in the eighteen and nineteen century, the cessation of which contributed to the release of particulate mine waste to the estuary [29].

Camel estuary is significantly enriched in $\mathrm{Sn}, \mathrm{W}$ and $\mathrm{Zr}$, sourced from the release of particulate mine wastes directly from the hard-rock mining activities at Mulberry and Lanivet region where large quantities of cassiterite were discharged into the estuary through local streams [27]. The geochemical elemental profile of the estuarine sediments in this study indicates the composition of mining related sediment supplied to the estuarine system.

Of all the estuaries, the Gannel is recognised to contain the highest $\mathrm{Pb}$ contamination of any estuary in the South-West England [27]. The geochemical parameters of the sediments analysed here indicate that the sediment might have been sourced from particulate waste from mining activity centred on cross-course mineralisation [26]. Previous work in the estuary $[25,26]$ clearly suggest that Gannel Estuary received highly significant particulate wastes from mines working with "Pb-Ag-Zn lodes" [26].

From the results presented in this study, it can be stated that the elemental composition of the geochemical of both the estuarine and beach/open coast sediment samples show that the build-up of the inter-tidal sediments in the estuaries are as a result of offshore sources combined with the onshore sediments transported into the estuaries (which have been impacted as a result of human activities, notably mining). The almost equal concentration of the major biogenic elements in all of the estuaries supports the view that the valleys of the estuaries, with the infilling of sediments of similar geochemical content at almost equal proportion, are derived as a result of flood of the early Holocene in forming the present/modern estuary [26]. Aluminium, potassium, manganese and iron $(\mathrm{Al}, \mathrm{K}, \mathrm{Mn}$, and $\mathrm{Fe})$ are the dominant signals for the terrestrial/onshore inputs into the sediments in the region. The sedimentary concentrations of these elements follow similar pattern in all of the estuaries. This indicates, here, that both onshore and offshore contributions (evidenced by the concentration of marine elements such as $\mathrm{Mg}$, $\mathrm{Sr}$, and so on) also interplay in supplying sediments to the estuaries. In addition, one of the most important contributors to the siltation of the estuaries in the 19th and 20th century is the release of particulate waste from upstream mining.

\section{Conclusion}

The XRF geochemical and mineralogical compositions of sediment show the levels of mine waste tailings in the estuarine system analysed here which is as a result of major historical mining activities with $\mathrm{Sn}$, $\mathrm{Cu}$, As and $\mathrm{Zn}$ as predominantly significant in Hayle, $\mathrm{Pb}$ and $\mathrm{Zn}$ in Gannel and Sn, W, and $\mathrm{Zr}$ in Camel estuaries respectively corresponding with the historical mining industries in each of the systems. The effects of the release of these particulate mine waste are still significantly observed in the sample sediments' mineralogical composition despite the cessation of the mine activities in the $19^{\text {th }} /$ early $20^{\text {th }}$ Century suggesting that these elements are still bio-available and bio-active for riverine processes to transport/migrate in the estuary - coast interaction. This study has shown, therefore, that the signature of anthropogenic activities (e.g. mining) has effects that is beyond the years of their operation and cessation, and has also confirmed that there is a strong sedimentary link between heavy metal contamination and historical mining activities in the Southwest England coastal-estuarine environment.

\section{Acknowledgement}

Sincere appreciation to my $\mathrm{PhD}$ supervisors: $\mathrm{Dr}$ Helene Burningham and Prof Jon French for their support when this project was undertaken as part of my $\mathrm{PhD}$ Geography programme at University College London.

\section{References}

1. Antizar-Ladislao B, Mondal P, Mitra S, Sarkar SK (2015) Assessment of trace metal contamination level and toxicity in sediments from coastal regions of West Bengal, eastern part of India. Marine Pollution Bulletin: 101.

2. Popadic A, Vidovi J, Cosovic SV, Medakovic D, Matej D (2013) Impact evaluation of the industrial activities in the Bay of Bakar (Adriatic Sea, Croatia): recent benthic foraminifera and heavy metals. Mar Pollut Bull 76: 333-348.

3. Wang ZH, Feng J, Nie XP (2015) Recent environmental changes reflected by metals and biogenic elements in sediments from the Guishan Island, the Pearl River Estuary, China. Estuarine, Coastal and Shelf Science 164: 493-505.

4. Bodin N, N'Gom-Ka RS, Ka OT, Thiaw L, Tito de Morais F (2013) Assessment of trace metal contamination in mangrove ecosystems from Senegal, West Africa. Chemosphere 90: 150-157.

5. Chapman PM, Wang F, Caeiro SS (2013) Assessing and managing sediment contamination in transitional waters. Environ Int 55: 71-91.

6. Viles HA, Spencer T (1995) Coastal Problems: Geomorphology, Ecology and Society at the Coast. London, Edward Arnold.

7. Wang ZH, Feng J, Nie XP (2015) Recent environmental changes reflected by metals and biogenic elements in sediments from the Guishan Island, the Pearl River Estuary, China. Estuarine, Coastal and Shelf Science 164: 493-505. 
Citation: Oyedotun TDT (2016) Historical Mining Signatures: Geochemical and Mineralogical Evaluation of Sediments in three CoastalEstuarine Systems. J Coast Zone Manag 19: 432. doi:10.4172/2473-3350.1000432

Page 6 of 6

8. Young SM, Pitawala A, Ishiga H (2013) Geochemical characteristics of stream sediments, sediment fractions, soils, and basement rocks from the Mahaweli River and its catchment, Sri Lanka. Chemie der Erde 73: 357-371.

9. Dissanayake CB, Chandrajith R (2003) Gem-bearing Stream Sediments of Sri Lanka. Publication of the Gem and Jewellery Research and Training Institute and National Gem and Jewellery Authority, Colombo, Sri Lanka: 121.

10. Defra (2006) Flood and Coastal Defence Appraisal Guidance FCDAG3 Economic Appraisal. Supplementary Note to Operating AuthoritiesClimate Change Impacts.

11. Buscomb DD, Scott TM (2008) The Coastal Geomorphology of North Cornwall: St Ives Head to Trevose Head. Wave hub Impact on Seabed and Shoreline Processes (WHISSP). University of Plymouth.

12. Davidson NC, Laffoley DD, Way LS, Key R, Drake CM (1991) Nature conservation and estuaries in Great Britain, Nature Conservancy Council, Peterborough, UK.

13. Oyedotun TDT, Burningham H, French JR (2012) Characterisation of estuary and adjacent beach sediments in the Gannel Estuary, south-west England. Geoscience in south-west England 13: 70-76.

14. Hollick LM, Shail RK, Leveridge BE (2006) Devonian rift-related sedimentation and Variscan tectonics - new data on the Looe and Gramscatho basins from the resurvey of the Newquay District. Geoscience in south-west England 11: 191-198.

15. Brew DS, Gibberd BB (2009) Geomorphological change and its impact on habitats in the Camel Estuary, Cornwall, UK. Geoscience in South-West England 12: 95-100.

16. Oyedotun TDT, Burningham H, French JR (2013) Sediment sorting and mixing in the Camel Estuary, UK. In: Conley DC, Masserlink G, Russell $\mathrm{PE}$ and O'Hare TJ (Eds), Proceedings 12th International Coastal Symposium (Plymouth, England). Journal of Coastal Research 65: 1563-1568.

17. Buck AL (1993) An Inventory of UK Estuaries. Volume 2 South-west Britain. Peterborough, Joint Nature Conservation Committee.

18. Defra. 2002. Futurecoast. Defra.

19. Bloemsma MR, Zabel M, Stuut JBW, Tjallingii R, Collins JA, et al. (2012) Modelling the joint variability of grain size and chemical composition in sediment. Sedimentary Geology 280: 135-148.

20. Norrish K, Chappell (1977) X-ray Flourescence Spectrometry, In Physical Methods in Determinative Mineralogy, 2nd Edition ed. J. Zussman, (eds), Academic Press: 201-272.

21. Hammer O, Harper DAT, Ryan RD (2001) PAST: Paleontological statistics software package for education and data analysis. Palaeontologia Electronica 4: 9 .
22. Salminen R, Batista MJ, Bidovec M, Demetriades A, De Vivo B, et al. (2005) Geochemical Atlas of Europe. Part 1 - Background Information, Methodology and Maps. Geological Survey of Finland.

23. Reimann C, De Caritat P (1998) Chemical Elements in the Environment, Factsheets for the Geochemist and Environmental Scientist, SpringerVerlag: 398.

24. Oyedotun TDT (2015) Tale of three estuaries: Comparative evaluation of geochemical and mineraological intertidal sediments in North Cornwall, Southwest England. 21st International Conference on Environmental Indicators, University of Windsor. International Society of Environmental Indicators Journal.

25. Pirrie D, Camm GS (1999) The impact of mining on sedimentation in the coastal zone of Cornwall. In: Scourse JD, Furze MFA (Eds.) The Quaternary of West Cornwall. Field Guide, Quaternary Research Association, London: 62-73.

26. Pirrie D, Power MR, Wheeler PD, Ball AS (2000) A new occurrence of diagenetic simonkolleite from the Gannel Estuary, Cornwall. Geoscience in South-West England 10: 18-20.

27. Pirrie D, Power MR, Payne GS, Wheeler PD (2000) Impact of mining on sedimentation: The Camel and Gannel estuaries, Cornwall. Geoscience in South-West England 10: 21-28.

28. Pirrie D, Power MR, Wheeler PD, Cundy A, Bridges C, et al. (2002) Geochemical signature of historical mining: Fowey Estuary, Cornwall, UK. Journal of Geochemical Exploration 76: 31-43.

29. Rollinson GK, Pirrie D, Power MR, Cundy A, Camm GS (2007) Geochemical and mineralogical record of historical mining, Hayle Estuary, Cornwall, UK. Geoscience in South-West England: 326-337.

30. Friend PL, Velegrakis AF, Weatherston PD, Collins MB (2006) Sediment transport pathways in a dredged ria system, southwest England. Estuarine, Coastal and Shelf Science 67: 491-502.

31. Hughes SH (2000) The geochemical and mineralogical record of the impact of historical mining within estuarine sediments; Fal estuary, Cornwall, UK.

32. Pirrie D, Hughes SH, Camm GS (1999) Late Holocene sedimentation due to mine waste discharge, Fai Estuary. In: The Quaternary of West Cornwall JD, Scourse \& Furze MFA (eds) London: Field Guide, Quarternary Research Association: 113-121.

33. Hosking KFG, Ong PM (1963) The distribution of tin and certain other heavy metals in the superficial portions of the Gwithian/Hayle beach of West Cornwall. Transactions of the Royal Geological Society of Cornwall. Lanka. Chemie der Erde 73: 357-371. 